Medical Principles and Practice
Med Princ Pract 2013;22:42-46

DOI: $\underline{10.1159 / 000340065}$
Received: February 29, 2012

Accepted: June 12, 2012

Published online: August 9, 2012

This is an Open Access article licensed under the terms of the Creative Commons AttributionNonCommercial-NoDerivs 3.0 License (www.karger.com/OA-license), applicable to the online

version of the article only. Distribution for non-commercial purposes only.

\title{
Epicardial Adipose Tissue Increased in Patients with Newly Diagnosed Subclinical Hypothyroidism
}

\author{
Levent Korkmaz $^{\mathrm{a}}$ Sinan Sahin ${ }^{\mathrm{b}} \quad$ Ali Riza Akyuz $^{\mathrm{a}} \quad$ Murat Ziyrek $^{\mathrm{b}}$ \\ Inan Anaforogluc ${ }^{c}$ Mustafa Kose ${ }^{c}$ Hakan Erkan $^{a}$ Mustafa Tarık Ağaça \\ Zeydin Acar $^{\mathrm{a}}$ \\ a Department of Cardiology, Ahi Evren Thoracic and Cardiovascular Surgery Training and Research Hospital, \\ and Departments of ${ }^{b}$ Cardiology and ${ }^{c}$ Endocrinology, Trabzon Numune Training and Research Hospital, \\ Trabzon, Turkey
}

\section{Key Words}

Epicardial fat $\cdot$ Coronary heart disease $\cdot$ Subclinical

hypothyroidism

\begin{abstract}
Objective: To investigate whether or not patients with subclinical hypothyroidism (SH) have increased epicardial adipose tissue (EAT). Subjects and Methods: Sixty-one patients with newly diagnosed $\mathrm{SH}$ and without any known cardiovascular disease were enrolled. Twenty-four subjects matched for age, gender and body mass index without any thyroid dysfunctions were included as a control group. The EAT was measured by echocardiography and thyroid functions were assessed by routine blood examination. Results: Patients with SH had higher EAT values than control subjects (3.6 \pm 0.9 vs. $2.8 \pm 1.4, p=0.005)$. Also, SH patients with thyroidstimulating hormone (TSH) $\geq 10 \mathrm{mU} / \mathrm{l}$ had higher EAT than those with SH with TSH $<10 \mathrm{mU} / \mathrm{l}$ and control subjects $(p=$ 0.013 ). In addition, while there was significant correlation between EAT and TSH $(r=0.31, p=0.014)$ in patients with SH, there was no significant relation between EAT and TSH in normal subjects $(r=0.09, p=0.64)$. Conclusions: There was a higher level of EAT in patients with SH compared with normal subjects and a significant correlation between EAT and TSH was found.

Copyright @ 2012 S. Karger AG, Basel
\end{abstract}

\section{Introduction}

Epicardial adipose tissue (EAT) is a visceral fat depot in the heart. In the normal adult, it is concentrated in the atrioventricular and interventricular grooves and along the major branches of the coronary arteries, and, to a lesser extent, around the atria, over the free wall of the right ventricle and over the apex of the left ventricle [1]. Evidence is accumulating that EAT can directly regulate vasomotor function by diffusion of its bioactive molecules into the nearby intima-media layer of the vessel wall [2, 3]. It has been shown that coronary atherosclerosis can be directly influenced by localized perivascular EAT [4]. Taking into account the putative proatherogenic property of EAT, several clinical studies have revealed that there is a correlation between the amount of EAT and coronary atherosclerosis [5-7].

Subclinical hypothyroidism ( $\mathrm{SH}$ ) is defined as elevated serum thyroid-stimulating hormone (TSH) with normal free $T_{4}$ and free $T_{3}$ levels. Several studies demonstrated that the risk of coronary heart disease (CHD) events is increased in SH $[8,9]$. Moreover, higher TSH levels even in the normal range are associated with an increased mass of visceral adipose tissue, which is an independent risk factor for the development of CHD [10, 11]. Echocardiographic epicardial fat strongly reflects the intra-ab-

\section{KARGER}

Fax +41613061234

E-Mail karger@karger.ch

www.karger.com
(C) 2012 S. Karger AG, Basel

1011-7571/13/0221-0042\$38.00/0

Accessible online at:

www.karger.com/mpp
Levent Korkmaz, MD

Department of Cardiology

Ahi Evren Thoracic and Cardiovascular Surgery

Training and Research Hospital, Trabzon (Turkey)

E-Maill.korkmaz@yahoo.com 


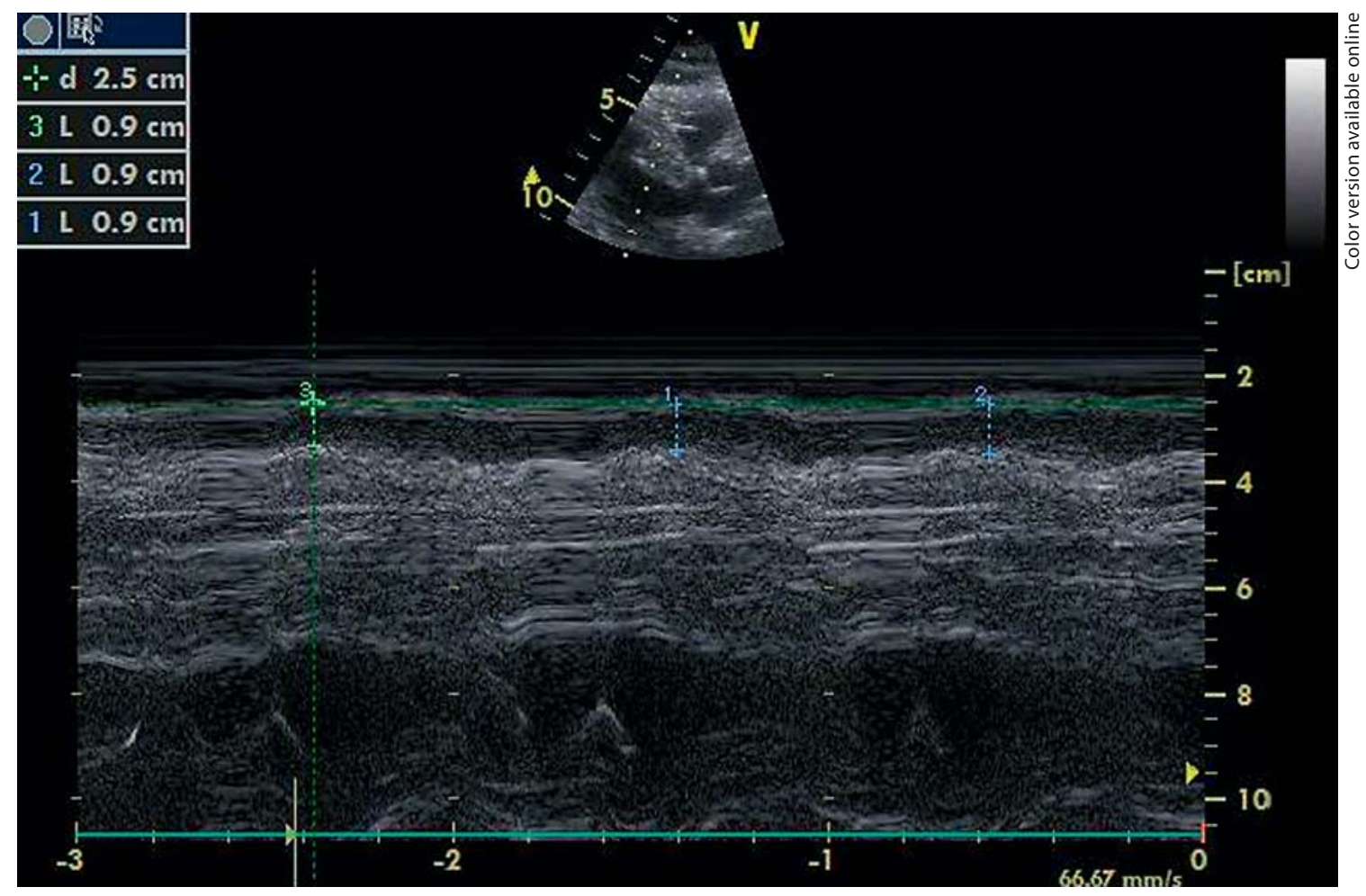

Fig. 1. Measurement of epicardial fat by echocardiography.

dominal accumulation of visceral fat and is an independent predictor of visceral adiposity [12]. Thus, we hypothesized that EAT might be increased in patients with $\mathrm{SH}$ and could, at least to some extent, contribute to the detrimental effect of $\mathrm{SH}$ in the development of cardiovascular disease. Therefore, the main purpose of this study was to test this hypothesis.

\section{Subjects and Methods}

\section{Study Populations}

Sixty-one consecutive patients admitted to the outpatient Endocrinology Clinic, Trabzon Numune Training and Research Hospital and considered to have SH were enrolled in this study. None of them had any known or suspected cardiovascular disease based on the clinical history or laboratory evaluations such as electrocardiography or echocardiography or had taken any thyroid medications. Twenty-four age- and gender-matched subjects with no thyroid dysfunctions were enrolled from those admitted to the same clinic. The Ethics Committee of Trabzon Numune Training and Research Hospital approved the study.

\section{Assessment of Thyroid Function}

Serum TSH and free $\mathrm{T}_{4}$ were measured in all subjects. Informed consent was obtained from all subjects that were enrolled.

\section{Measurement of EAT}

Each subject underwent detailed transthoracic two-dimensional, M-mode, Doppler, and tissue Doppler echocardiography using standardized techniques (fig. 1). Echocardiogram was performed by an experienced physician (A.R.A.), who was blinded to the subjects' clinical and demographic data. Each subject underwent transthoracic two-dimensional guided M-mode echocardiography using commercially available equipment (Esaote Mylab50). Standard parasternal and apical views were obtained in the left lateral decubitus position. Epicardial fat was identified as echocardiographic free space between the outer wall of the myocardium and the visceral layer of the pericardium. Epicardial fat thickness was measured perpendicularly on the free wall of the right ventricle at end diastole in 3 cardiac cycles. Parasternal longand short-axis views allowed the most accurate measurement of EAT in the right ventricle, with optimal cursor beam orientation in each view. Maximum epicardial fat thickness was measured at the point on the free wall of the right ventricle along the midline of the ultrasound beam, perpendicular to the aortic annulus, and used as an anatomic landmark for this view. For midventricular parasternal short-axis assessment, maximum epicardial fat thickness was measured on the right ventricular free wall along the midline of the ultrasound beam, perpendicular to the ventricular septum at the midchorda and tip of the papillary muscle level, as an anatomic landmark. The average value of 3 cardiac cycles from each echocardiographic view was considered. 
Table 1. Clinical and laboratory characteristics of the study population $(\mathrm{n}=85)$

\begin{tabular}{lccc}
\hline & $\begin{array}{c}\text { Control } \\
(\mathrm{n}=24)\end{array}$ & $\begin{array}{c}\text { Patient } \\
(\mathrm{n}=61)\end{array}$ & p value \\
\hline Age, years & $43 \pm 17$ & $44 \pm 14$ & 0.93 \\
Male/female & $5 / 19$ & $7 / 54$ & 0.07 \\
Hypertension & $5(20)$ & $9(15)$ & 0.4 \\
Diabetes & $1(0.04)$ & $4(0.06)$ & 0.23 \\
Dyslipidemia & $1(0.04)$ & $2(0.03)$ & 0.66 \\
Smoking & $2(0.08)$ & $4(0.07)$ & 0.25 \\
Total cholesterol, mg/dl & $186 \pm 32$ & $191 \pm 44$ & 0.65 \\
LDL, mg/dl & $120 \pm 28$ & $130 \pm 31$ & 0.28 \\
HDL, mg/dl & $51 \pm 11$ & $49 \pm 10$ & 0.66 \\
Triglyceride, mg/dl & $115 \pm 46$ & $147 \pm 68$ & 0.1 \\
BMI, kg/m & $33.1 \pm 6.2$ & $33.2 \pm 6.3$ & 0.9 \\
Epicardial fat, mm & $2.8 \pm 1.4$ & $3.6 \pm 0.9$ & 0.005 \\
TSH, mU/l & $1.5 \pm 0.9$ & $9.3 \pm 5.6$ & $<0.001$ \\
$\mathrm{~T}_{4}, \mathrm{ng} / \mathrm{dl}$ & $1.2 \pm 0.2$ & $1.1 \pm 0.3$ & 0.39 \\
$\mathrm{~T}_{3}, \mathrm{pmol} / \mathrm{l}$ & $2.9 \pm 0.7$ & $2.7 \pm 0.4$ & 0.29 \\
\hline
\end{tabular}

Values are expressed as means \pm SD or numbers with percentages in parentheses.

$\mathrm{BMI}=$ Body mass index LDL = low-density lipoprotein cholesterol; HDL = high-density lipoprotein cholesterol.

\section{Statistical Analysis}

Continuous variables were expressed as mean \pm standard deviation and categorical variables were expressed as a percentage. Analysis of the normality of the continuous variables was performed with the Kolmogorov-Smirnov test. Mann-Whitney U, $\chi^{2}$ and independent samples t test were performed when comparing clinical and laboratory characteristics of patients and control subjects. The Spearman correlation analysis was used for assessing the correlation between TSH and EAT. In order to assess the relation between SH severity and EAT, one-way ANOVA with post hoc Tukey was performed. Statistical analysis was performed by using SPSS 14.0 and a $\mathrm{p} \leq 0.05$ (two-tailed) was considered significant.

\section{Results}

Clinical and laboratory characteristics of the study population are shown in table 1 . Mean age was $43 \pm 15$ and most of the subjects were female. Sixty-one patients were diagnosed with SH. There were no significant differences regarding clinical and laboratory characteristics between patients and control groups except TSH ( $\mathrm{p}=$ 0.001 ) and epicardial fat thickness ( $\mathrm{p}=0.005$, table 1$)$. In our laboratory, the normal range for free $\mathrm{T}_{4}$ and $\mathrm{TSH}$ was $0.7-1.48 \mathrm{ng} / \mathrm{day}$ and $0.35-4.94 \mathrm{mU} / \mathrm{l}$, respectively. Pa-
Table 2. Clinical and laboratory characteristics of patients with $\mathrm{SH}(\mathrm{n}=61)$

\begin{tabular}{lccc}
\hline & $\begin{array}{c}\text { TSH }<10 \\
(\mathrm{n}=42)\end{array}$ & $\begin{array}{c}\text { TSH } \geq 10 \\
(\mathrm{n}=19)\end{array}$ & p value \\
\hline Age, years & $43 \pm 13$ & $46 \pm 15$ & 0.4 \\
Male/female & $5 / 37$ & $2 / 17$ & 0.17 \\
BMI, kg/m ${ }^{2}$ & $32.8 \pm 6.2$ & $33.6 \pm 6.3$ & 0.08 \\
Hypertension & $6(14)$ & $3(15)$ & 0.4 \\
Diabetes & $2(0.04)$ & $2(0.1)$ & 0.32 \\
Dyslipidemia & $1(0.02)$ & $1(0.05)$ & 0.21 \\
Smoking & $2(0.04)$ & $1(0.05)$ & 0.84 \\
Triglyceride, mg/dl & $140 \pm 66$ & $169 \pm 73$ & 0.07 \\
LDL, mg/dl & $123 \pm 29$ & $135 \pm 31$ & 0.42 \\
HDL, mg/dl & $50 \pm 11$ & $45 \pm 6$ & 0.13 \\
Total cholesterol, mg/dl & $190 \pm 33$ & $216 \pm 57$ & 0.65 \\
Epicardial fat, mm & $3.5 \pm 0.9$ & $4.1 \pm 0.8$ & 0.06 \\
TSH, mU/l & $6.7 \pm 1.4$ & $16.2 \pm 5.2$ & $<0.001$ \\
$\mathrm{~T}_{4}$, ng/dl & $1.16 \pm 0.28$ & $1.01 \pm 0.15$ & 0.033 \\
$\mathrm{~T}_{3}, \mathrm{pmol} / \mathrm{l}$ & $2.9 \pm 0.35$ & $2.4 \pm 0.41$ & 0.024 \\
\hline
\end{tabular}

Values are expressed as means \pm SD or numbers with percentages in parentheses.

$\mathrm{BMI}=$ Body mass index; LDL = low-density lipoprotein cholesterol; $\mathrm{HDL}=$ high-density lipoprotein cholesterol.

tients with SH had higher EAT compared with control subjects ( $3.6 \pm 0.9$ vs. $2.8 \pm 1.4, \mathrm{p}=0.005$, table 2$)$. The demographics and laboratory characteristics of patients with high and moderately increased TSH values are presented in table 2 . SH patients with $\mathrm{TSH} \geq 10 \mathrm{mU} / \mathrm{l}$ ( $\mathrm{n}=$ 19) had higher EAT than those with TSH $<10 \mathrm{mU} / \mathrm{l}$ ( $\mathrm{n}=$ $42)$ and control subjects $(4.1 \pm 0.8$ vs. $3.5 \pm 0.9$ and 3.0 \pm 1.3 , respectively, $\mathrm{p}=0.013)$. In addition, there was a significant positive correlation between EAT and TSH in SH patients $(\mathrm{r}=0.31, \mathrm{p}=0.014)$ but not in control subjects $(\mathrm{r}=0.09, \mathrm{p}=0.64)$.

\section{Discussion}

We demonstrated higher levels of EAT in patients with $\mathrm{SH}$ than in controls. This may help explain the pathological mechanisms of thyroid dysfunctions related to cardiovascular disease.

Atherosclerosis and myocardial infarction were more common in patients with SH [13]. Also, $\mathrm{SH}$ was associated with increased CHD prevalence and all-cause mortality independent of CHD risk factors [14]. Even though studies have revealed an association between $\mathrm{SH}$ and $\mathrm{CHD}$ and 
its related complications, the underlying pathological mechanisms are not well understood. SH is associated with hypertension, hypertriglyceridemia, and elevated total cholesterol/HDL cholesterol ratio [15]. The underlying mechanisms may include effects of thyroid on endothelial function, relaxation of smooth muscle cells [16], hypercoagulability [15], blood rheology [17], and inhibition of collagen-induced platelet aggregation [18]. Furthermore, there is a relation between visceral adipose tissue and TSH level and the presence of TSH receptors on adipocytes during differentiation and fully differentiated adipocytes have been demonstrated as well [19]. Therefore, it could be argued that elevated TSH levels may lead to increased visceral adipose tissue mass and function and subsequently to an increased cardiovascular risk.

Epicardial adipose volume positively relates to coronary atherosclerotic burden [20] and epicardial fat area measurements in a single area reflect total epicardial fat volume [21]. Also, not baseline but an increase in EAT is associated with greater progression of coronary artery calcification which is a surrogate marker of atherosclerosis [22]. EAT may be linked with the development of coronary atherosclerosis through several paracrine mechanisms, such as the local release of inflammatory mediators that trigger the atherosclerotic process, and other systemic effects $[1,23,24]$. Epicardial fat might contribute to atherosclerosis not only through the secretion of bioactive molecules but also by specific mechanical effects. Due to its intrinsic compressibility, epicardial fat has therefore been suggested to play a permissive role in vessel expansion that leads to an asymmetric expansion of the vessel wall being defined as positive vessel remodeling [25].

An exclusive role of epicardial fat in the development of atherosclerosis has also been hypothesized. Pericardial adipose tissue is part of EAT that directly surrounds the coronary arteries and has been suggested to contribute to the development of CHD [26]. Studies suggested that adipocytokines produced by pericardial adipose tissue might amplify vascular inflammation through paracrine effects, leading to local atherogenesis, plaque instability, and neovascularization $[27,28]$. These findings suggest that coronary atherosclerosis may be mediated by local effects of pericardial adipose tissue in addition to systemic inflammatory processes.

To date no study has investigated yet the relation between epicardial fat and thyroid functions; our explanation for increased EAT in hypothyroid patients compared to normal subjects is hypothetical. Epicardial fat is an additional visceral fat depot surrounding the heart and

shares the same embryologic origin with abdominal visceral fat [1]. EAT is an independent predictor of visceral fat [12]. In addition, there was a significant association between TSH levels and amount of visceral fat [11]. Moreover, increased TSH receptor expression that may have a possible role in cardiac function and pathophysiology has been demonstrated in EAT [29]. Therefore, it may be logical to think that increased cardiovascular events in $\mathrm{SH}$ patients may be attributable to EAT.

There are several limitations to our study. First of all, the number of patients is relatively small. Secondly, since our study is cross-sectional, we cannot determine whether patients with increased EAT may have an increased incidence of CHD. Also, our study design does not allow us to discuss in detail the pathophysiological mechanisms responsible for increased EAT in this patient population. The other important limitation of our study is the lack of data on the duration of thyroid dysfunction. Since patients with $\mathrm{SH}$ are generally asymptomatic, we did not record this and did not include it in statistical analysis. Therefore, it cannot be ruled out that not only TSH value but also disease duration may be important for increased EAT.

\section{Conclusion}

We demonstrated higher EAT in patients with $\mathrm{SH}$ and a significant correlation between EAT and TSH. The clinical significance of this relation and the impact of thyroid medications on epicardial fat and clinical outcomes require further research.

References

Med Princ Pract 2013;22:42-46
1 Iacobellis G, Corradi D, Sharma AM: Epicardial adipose tissue: anatomic, biomolecular and clinical relationships with the heart. Nat Clin Pract Cardiovasc Med 2005;2:536-543.

2 Yudkin JS, Eringa E, Stehouwer CD: 'Vasocrine' signalling from perivascular fat: a mechanism linking insulin resistance to vascular disease. Lancet 2005;365:1817-1820.

3 Sacks HS, Fain JN: Human epicardial adipose tissue: a review. Am Heart J 2007;153: 907-917.

$\checkmark 4$ Wang TD, Lee WJ, Shih FY, Huang CH, Chen WJ, Lee YT, Shih TT, Chen MF: Association of epicardial adipose tissue with coronary atherosclerosis is region-specific and independent of conventional risk factors and intra-abdominal adiposity. Atherosclerosis 2010;213:279-287. 
5 Sarin S, Wenger C, Marwaha A, Qureshi A, Go BD, Woomert CA, Clark K, Nassef LA, Shirani J: Clinical significance of epicardial fat measured using cardiac multislice computed tomography. Am J Cardiol 2008;102: 767-771.

6 Ding J, Hsu FC, Harris TB, et al: The association of pericardial fat with incident coronary heart disease: the Multi Ethnic Study of Atherosclerosis (MESA). Am J Clin Nutr 2009;90:499-504.

7 Chaowalit N, Somers VK, Pellikka PA, Rihal CS, Lopez-Jimenez F: Subepicardial adipose tissue and the presence and severity of coronary artery disease. Atherosclerosis 2006; 186:354-359.

$\checkmark 8$ Gorter PM, de Vos AM, van der GraafY, Stella PR, Doevendans PA, Meijs MF, Prokop M, Visseren FL: Relation of epicardial and pericoronary fat to coronary atherosclerosis and coronary artery calcium in patients undergoing coronary angiography. Am J Cardiol 2008;102:380-385.

-9 Biondi B, Palmieri EA, Lombardi G, Fazio S: Effects of subclinical thyroid dysfunction on the heart. Ann Intern Med 2002;137:904914.

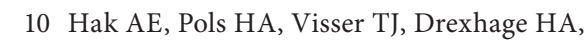
Hofman A, Witteman JC: Subclinical hypothyroidism is an independent risk factor for atherosclerosis and myocardial infarction in elderly women: the Rotterdam Study. Ann Intern Med 2000;132:270-278.

11 Westerink J, van der Graaf Y, Faber DR, Visseren FL; SMART study group: The relation between thyroid-stimulating hormone and measures of adiposity in patients with manifest vascular disease. Eur J Clin Invest 2011;41:159-166.

12 Iacobellis G, Assael F, Ribaudo MC, Zappaterreno A, Alessi G, Di Mario U, Leonetti F: Epicardial fat from echocardiography: a new method for visceral adipose tissue prediction. Obes Res 2003;11:304-310.

13 Cappola AR, Ladenson PW: Hypothyroidism and atherosclerosis. J Clin Endocrinol Metab 2003;88:2438-2444.
4 McQuade C, Skugor M, Brennan DM, Hoar B, Stevenson C, Hoogwerf BJ: Hypothyroidism and moderate subclinical hypothyroidism are associated with increased all-cause mortality independent of coronary heart disease risk factors: a PreCIS database study. Thyroid 2011;21:837-843.

15 Ishikawa T, Chijiwa T, Hagiwara M, Mamiya $\mathrm{S}$, Hidaka H: Thyroid hormones directly interact with muscular smooth muscle strips. Mol Pharmacol 1989;35:760-765.

16 Luboshitzky R, Aviv A, Herer P, Lavie L: Risk factors for cardiovascular disease in women with subclinical hypothyroidism. Thyroid 2002;12:421-425.

17 Chadarevian R, Bruckert E, Ankri A, Beucler I, Giral P, Turpin G: Relationship between thyroid hormones and plasma D-dimer levels. Thromb Haemost 1998;79:99103.

18 Költringer P, Eber O, Wakonig P, Klima G, Lind P: Hypothyroidism and the influence on human blood rheology. J Endocrinol Invest 1988;11:267-272.

19 Mamiya S, Hagiwara M, Inoue S, Hidaka H: Thyroid hormones inhibit platelet function and myosin light chain kinase. J Biol Chem 1989;264:8575-8579.

20 Lu M, Lin RY: TSH stimulates adipogenesis in mouse embryonic stem cells. J Endocrinol 2008;196:159-169.

21 Oyama N, Goto D, Ito YM, Ishimori N, Mimura R, Furumoto T, Kato F, Tsutsui $\mathrm{H}$, Tamaki N, Terae S, Shirato H: Single-slice epicardial fat area measurement: do we need to measure the total epicardial fat volume? Jpn J Radiol 2011;29:104-109.

22 Bettencourt N, Toschke AM, Leite D, Rocha J, Carvalho M, Sampaio F, Xará S, LeiteMoreira A, Nagel E, Gama V: Epicardial adipose tissue is an independent predictor of coronary atherosclerotic burden. Int J Cardiol 2012;158:26-32.
23 Nakanishi R, Rajani R, Cheng VY, Gransar $H$, Nakazato R, Shmilovich H, Otaki Y, Hayes SW, Thomson LE, Friedman JD, et al: Increase in epicardial fat volume is associated with greater coronary artery calcification progression in subjects at intermediate risk by coronary calcium score: a serial study using non-contrast cardiac CT. Atherosclerosis 2011;218:363-368.

24 Mazurek T, Zhang L, Zalewski A, Mannion JD, Diehl JT, Arafat H, Sarov-Blat L, O’Brien S, Keiper EA, Johnson AG, et al: Human epicardial adipose tissue is a source of inflammatory mediators. Circulation 2003;108: 2460-2466.

25 Iacobellis G, Pistilli D, Gucciardo M, Leonetti F, Miraldi F, Brancaccio G, Gallo P, di Gioia CR: Adiponectin expression in human epicardial adipose tissue in vivo is lower in patients with coronary artery disease. Cytokine 2005;29:251-255.

26 Prati F, Arbustini E, Labellarte A, Sommariva L, Pawlowski T, Manzoli A, Pagano A, Motolese M, Boccanelli A: Eccentric atherosclerotic plaques with positive remodelling have a pericardial distribution: a permissive role of epicardial fat? A three-dimensional intravascular ultrasound study of left anterior descending artery lesions. Eur Heart J 2003;24:329-336.

$\checkmark 27$ Maurovich-Horvat P, Kallianos K, Engel LC, Szymonifka J, Fox CS, Hofmann U, Truong QA: Influence of pericoronary adipose tissue on local coronary atherosclerosis as assessed by a novel MDCT volumetric method. Atherosclerosis 2011;219:151-157.

- 28 Gorter PM, de Vos AM, van der GraafY, Stella PR, Doevendans PA, Meijs MF, Prokop M, Visseren FL: Relation of epicardial and pericoronary fat to coronary atherosclerosis and coronary artery calcium in patients undergoing coronary angiography. Am J Cardiol 2008;102:380-385.

-29 Sellitti DF, Hill R, Doi SQ, Akamizu T, Czaja J, Tao S, Koshiyama H: Differential expression of thyrotropin receptor mRNA in the porcine heart. Thyroid 1997;7:641-646. 